\title{
The Ta ${ }^{c}$ ziya Ecstasy as Political Expression
}

\author{
By JAN HJÄRPE
}

The cover of a number of the Iranian Islamic Republic Party Weekly Bulletin, ${ }^{1}$ from August 1981, consists of a picture, a drawing representing a large building, demolished evidently by a bomb planted there by some enemy. Among the debris we can see pools of blood. Outlined against the dark sky above we read the words:

bi-'ayyi dhanbin kutilat ("for what sin she was slain")

Beneath the legend appears dimly a coffin carried by many hands. On the coffin is a carpet with the inscription

$y \bar{a}$ mażlüm Karbalä’ ("Oh Thou wronged one of Kerbela")

The picture, with its inscriptions, provides a highly concentrated illustration of how Islamic concepts and Shîi-Islamic historiography serve as patterns of interpretation in the political field in revolutionary Iran.

The picture of the demolished house symbolizes the activities of the militant opposition against the theocratic regime of Iran, especially the assassination of leading personalities by means of planted bombs. The inscriptions and the coffin hint at the regime's view of this opposition. They relate the events to the frames of reference, the "cognitive universes" (to use Peter Berger's terminology) of Shî ĩ Islam, and thus provide the legitimation, ${ }^{2}$ or part thereof, of the measures taken against the opposition. In other words, we find here religion as a pattern of interpretation, and thus also of behaviour; religion as a source of attitudes and feelings leading to political standpoints and acts.

The first legend is a quotation from the Quran, from the description of the Day of Resurrection and Doom, in Sura 81:

And when the female child that had been buried alive shall be asked (8) for what sin she was slain (9).

Traditionally this verse is seen as alluding to the pre-Islam Arab custom of the disposal of newborn children for whom they could not provide by

\footnotetext{
1 IRPWB 1: 44, Aug. 28, 1981, cover.

2 For this use of the term "legitimation", see Berger, 29.
} 
burying them alive. ${ }^{3}$ The quotation of these words constitutes an interpretation of the sabotage and the attempts on the lives of the leaders. The victims are innocent as newborn children, and the assassinations as criminal as the killing of those infants; a crime against God and his Law.

The coffin, carried by a host of hands, implying a crowd of mourners, is interpreted via the inscription and symbolizes an identity or similarity between those killed among the leading IRP members, and the victims of Kerbela and even some sort of identification with Imām Hụsayn himself.

The crucial event in the history (and the historiography) of Shî í Islam is the battle of Kerbela in Iraq ( 680 A D) where the third Shi'i I Imām, Muhammad's grandchild al-Husayn, fell attempting a revolt against the Umayyad Caliph Yazìd. ${ }^{4}$ In the Shī î historiography there is a multitude of traditions about Kerbela and all the persons involved, traditions about all they said, all they did, and everything that happened. Much of the material is obviously legendary, but even this, in all its detail, indicates the central role of Kerbela in the Shi ${ }^{-1} \mathrm{i}$ part of the Muslim world. ${ }^{5}$

The tragedy of Kerbela has left its mark on the spirituality of Shīism and its view of religion and politics. Shī îsm is the religion of sorrow, of martyrdom, of sentimentality, but also of opposition and insurrection. To put it in another way: Opposition and insurrection, self-sacrifice and hatred of enemies can find legitimation, i.e. patterns of interpretation, in the Shī ${ }^{-1}$ traditions of the martyrdom of Husayn and his followers at Kerbela. The drama constitutes a set of roles, with which one can identify oneself and one's friends and enemies; because the drama of Kerbela is alive, living history, always present in the minds primarily by means of the liturgical repetition, the annual commemoration of Kerbela in the 'Āshūrä' celebration. ${ }^{6}$

Ta'ziya, "consolation", has become the Shi technical term for the liturgical mourning and commemoration of the martyred Imāms, particularly the ritual lamentation for the death of Husayn, celebrated formerly often in the form of passion plays in which the heart is the drama of Kerbela, but in which in addition the whole of human history is viewed sub specie Kerbelae. Nowadays the celebration is first and foremost in the form of processions (in our Western mass media called "demonstrations"), engag-

\footnotetext{
${ }^{3}$ Cf Andrae, KHÅ 1924, 220, and Paret ad loc. This interpretation of the verse is not the only possible one, cf Blachère $I, 37 \mathrm{f}$, but it is the one which would most readily come to the mind of the Muslim reader.

${ }^{4}$ For a comprehensive account of the insurrection and its consequences, see Veccia Vaglieri, $608 \mathrm{ff}$.
}

\footnotetext{
${ }^{5}$ For its role in contemporary Shīi î historiography, cf Ende, $153 \mathrm{ff}$ and $160 \mathrm{ff}$.

6 For the use of the term "role" here, and for the importance of the liturgical repetition in role-creation, cf Sundén 1966,, $51 \mathrm{ff}$, and passim, but especially $214 \mathrm{ff}$.
} 
ing huge masses of people in emotion-evoking behaviour, also including processions to the cemetery.

For the contents of the classical Shī ${ }^{-1}$ passion plays and their performance, and for the theological interpretation of the sacrifice of Husayn and the other martyrs, we refer the reader to the available literature on the subject. $^{7}$

The Ta ziya of Husayn falls in the month of Muharram, with its culmination on the 10th day (rūz-i katl, "the day of the murder"), the "Āshārā" festival, and is followed up by the mourning ceremony on the 40th day (rūzi arba'in) from the 'Āshūrä' (20th day of Șafar).

It is important to note the immense impact of the $\mathrm{Ta}^{\mathrm{c}}$ ziya on the emotions of the participant masses, emotions aroused by several means. We have here the suggestive sentimentality of the speeches held by the Mullās, dwelling on the tribulations and sufferings of Husayn and his family and followers, on the cruelty and baseness of his enemies, and on the courage of the 72 noble-hearted martyrs of Kerbela. In the processions, the emotions are aroused by the rhythmical repetition of formulae expressing mourning for the martyrs and hatred of their murderers. Many of the participants are dressed in shrouds, many wear chains, ropes and scourges, and the lamentations are accompanied by self-flagellation of the naked backs. People beat their breasts, some have put earth on their heads. Women weep, bewailing the pains of Husayn and the $72 .{ }^{8}$

With regard to the exaltation of the masses, the sentimental raptures of the participants, we may speak of the Ta ziya-ecstasy, ecstasy at least in the sense of self-induced excitement, but also ecstasy as abnormal states of consciousness, ${ }^{9}$ provoked by the flagellation, the repetition of the formulae etc, but not ecstasy in the sense of total loss of reaction to external stimuli. ${ }^{10}$

The feverish exaltation of the participants sometimes proves dangerous for others. The hatred of the murderers of the Imāms and the martyrs is channelled against non-Shīis, foreigners etc, identified in the excitement with the enemies of ahl al-bayt, the family of the Prophet. But the reaction can also occur in such a way that the positive component predominates: a fervent desire to help the oppressed, the wronged. ${ }^{11}$

The theological speculation and systematization around the tribulations of the Imāms constitute an important part of the Shī î interpretation of

7 See Monchi-Zadeh, passim, and for a short orientation Strothmann, $590 \mathrm{f}$.

${ }^{8}$ A very sympathetic account by an eyewitness from the year of the Revolution,

from the 'Āshūrā' in 1978, is given by Hunt, $87 \mathrm{f}$.

${ }^{9} \mathrm{Cf}$. Inge, 157.

${ }^{10}$ Cf. Sundén 1974, 50 f.

${ }^{11} \mathrm{Cf}$. Hunt, $88 \mathrm{f}$. 
existence. Some of this became relevant to political action during the Revolution (and afterwards). In a widely circulated pamphlet about martyrdom, Āyatullāh Murtaḍa Muṭahharĩ (himself killed during the Revolution and thus considered a martyr) ${ }^{12}$ explains the roles of the martyrs. $\mathrm{He}$ relates several of the traditions about the early martyrs, and the rules regarding their burial-their bodies shall not be washed and dressed in shrouds as in the case with the ordinary dead, but they are to be buried in their own blood-stained clothing. ${ }^{13}$ From the tales of the early martyrs he concludes that martyrdom is necessary to save Islam from corruption. The blood of the martyrs gives life to the whole Umma, and thus they live forever in the people. ${ }^{14}$ From the rules for burial he concludes that the martyrs are pure, the ablution is performed in their own blood.

The martyrs are like candles which are burnt out, ${ }^{15}$ giving their light to all believers. This theme frequently recurs in the "iconography" of the Revolution. ${ }^{16}$ In several respects the martyrs are above other human beings. Their "logic" surpasses the capacity of the ordinary man's comprehension, ${ }^{17}$ they have the power of intercession on Doomsday, etc. Martyrdom is a role to assume, a pattern to follow. Muțahhari quotes a prayer which is read on the nights of Ramadān:

Oh God! let us be killed in your way, in the company of your friend (Imam) and attain martyrdom. ${ }^{18}$

We can find allusions to this identification in the interpretation of the war with Iraq. Let me quote a passage in a message from Khumaynī:

A number of leading army officers were here with me two days ago, and they urged me to prohibit further visits here of the 'peace mission', for they would not quit fighting. They told me 'we entered the battlefields like Imam Hussein and we welcome a martyrdom like that of Hussein'. ${ }^{19}$ (Quoted from the English version printed in IRPWB)

The role ascribed to martyrdom is also stressed very strongly in the constitution of the Islamic Republic. ${ }^{20}$

Let us now consider the dates of some important events in Iran, not according to our Gregorian calendar but in the Islamic Hidjra calendar. We find that the first part of the month of Muharram is of significance, particularly the days around the "Ashūrä, the commemoration of the tragedy of Kerbela on the 10th day of the month.

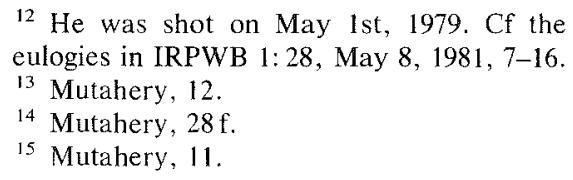

12 He was shot on May 1st, 1979. Cf the eulogies in IRPWB 1:28, May 8, 1981, 7-16.

13 Mutahery, 12.

14 Mutahery, $28 \mathrm{f}$.

15 Mutahery, 11.

16 The picture (Fig. 2) is reprinted frequently, e.g. in ash-Shahĩd.

${ }_{17}$ Mutahery, 26f.

18 Mutahery, 22.

19 IRPWB 1:38, July 27, 1981, 30.

${ }^{20}$ Kānūn-i asāsī, 5. 

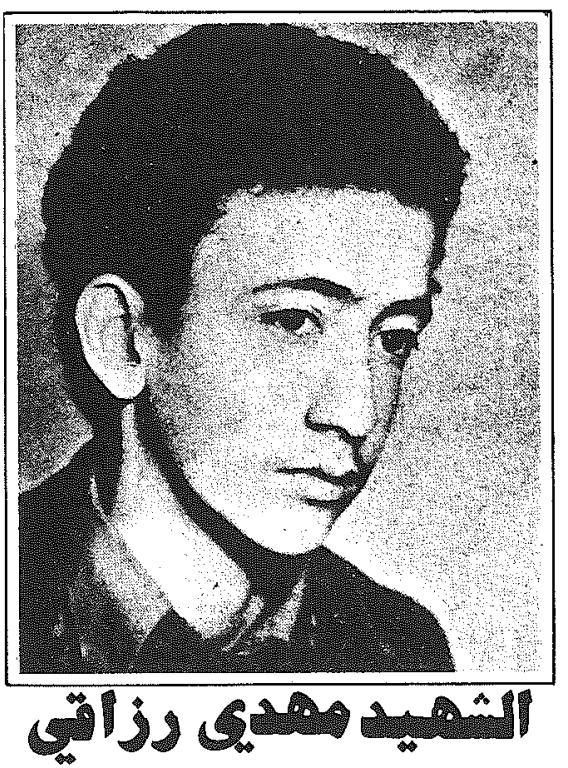

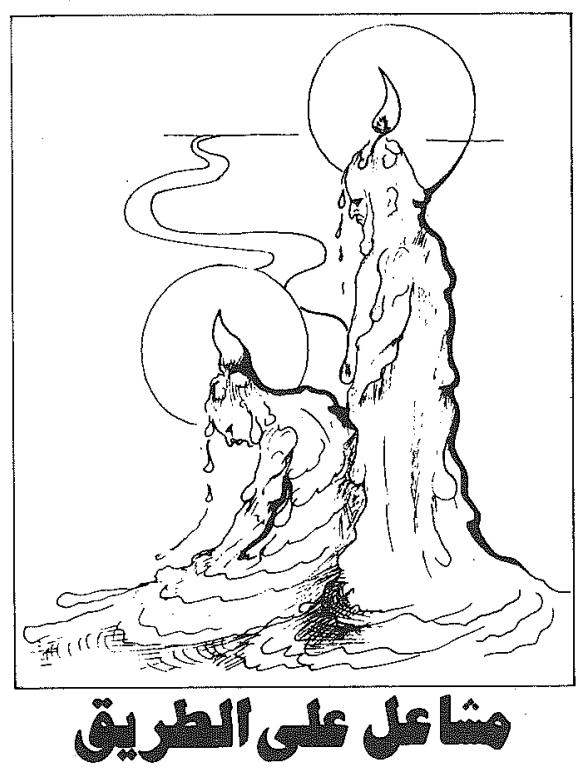

Fig. 1. Caption and inscription: "Caravan of Martyrs", "Lights on the road". (From ashShahīd 16/8 1399, 11/7 1979, 42.)

The uprising in 1963 (end of May, beginning of June) coincided with this period. This occasion was also the definitive break-through of Āyatullāh Khumayn $\mathbf{i}^{-1}$ as a popular and well-known religious leader. He was arrested on June 4th. On June 5th (in the Iranian calender: 15th of Khordad) occurred the great uprising against the Shah. In the Hidjra calendar it was the third day of the 'Āshürä'. In the revolutionaries' own historiography this was the beginning of the end for the Shah. Khumayni in a speech on the celebration of the anniversary of the uprising in 1981, makes the following statement (here quoted from the "English" version in IRPWB):

With its 'no' for an answer to the Yezidians, on the day of Ashura, Islam cast them away from the scene of all history and sent them to the grave, and so too our people sent the Pahlavid and the Pahlavians to the grave by their uprising /on the 5th of June $1963 / \ldots 22$

In Shî 1 i historiography the tragedy of Kerbela (in 680) is considered the beginning of the process which led to the fall of the Umayyads (in 750). ${ }^{23}$

In 1978 the 'Āshürä' coincided with the climax of the demonstrations against the Shah (10th and 11th December). The ritual cry "Death to

${ }^{21}$ Cf also Nyberg, 40.

22 IRPWB 1:33, June 12, 1981, 23.
${ }^{23}$ For contemporary Shī $\bar{i} \overline{\mathrm{i}}$ historiography and its tendencies, cf. Ende, 113-169. 
Yazìd" became the political slogan "Death to the Shah". The "Āshürā" processions assumed the role and function of demonstrations. ${ }^{24}$

In 1979 the days around the 10th of Muharram (the turn of the month November-December) were marked by huge demonstrations outside the then occupied ${ }^{25}$ US Embassy in Tehran. We could see pictures from the demonstrations on TV showing that many of the participants were dressed in shrouds, the symbolic expression of willingness to accept martyrdom. ${ }^{26}$

In 1980, the 'A Asshürä' celebration provided an interpretation of the war with Iraq-or rather, in the view of the regime in Tehran, the war imposed by the "atheist" Saddām Husayn. To fight in the war is considered "a Husaynic act". ${ }^{27}$ The concept of martyrdom, and the interiorization of this concept by the liturgical repetition, undoubtedly played a considerable role in creating the morale of the Iranians in their resistance against the Iraqi attack. Enthusiasm for martyrdom entails courage, self-sacrifice, perseverance, and also includes the frenetic hatred of those who are identified as "Yazidians". In combat, the Ta ziya ecstasy becomes a reality. ${ }^{27 a}$

We find these interpretative patterns all the time: Âyatullāh Khumaynī is called "heir of Husayn", "the Husayn of our time" etc, both in prose and in popular poetry, ${ }^{28}$ and the murderers of President Radjầ $\overline{1}$ are "worse than Ibn Muldjam" "29 (who killed "Alī b. Abĩ Tâalib). It is of special interest here to study the reactions to the blowing-up of the IRP Headquarters on June 28th (1981), where Beheshtī, among others, was killed. This event is obviously alluded to in the picture first mentioned.

News of the number of victims spread immediately: 72 people killed, and it was underlined that the June 28th martyrs were of the same number as the martyrs of Kerbela. ${ }^{30}$ Even when it became apparent that the number of victims was greater, the figure was retained. An editorial in the evening paper Kayhan after the deaths of Radjä $\overline{1}$ and Băhonar mentions the event of June 28th with the words "as a result of which more than 72 aides of Imam Khomeini ... were martyred". 31

Living history; the interpretation of the "now" is made by the comparison with the "then". I quote here from the description of the funeral of

${ }^{24}$ Cf. Hjärpe, 8.

${ }^{25}$ The Embassy was occupied on November 4th, i.e. immediately after the 'I Id al-aḍha that year. The Occupation coincided in time with the "Stoning of Satan" in the Hadjdj rituals. ${ }^{26} \mathrm{Cf}$ also Nyberg, 147.

${ }^{27}$ See e.g. Mahjubah 1: 1, April 1981, 17. 27 a For a description of the enthusiasm in battle, cf. e.g. Time, March 22, 1982, $32 \mathrm{f}$.
${ }^{28}$ See e.g. ash-Shahīd, 13th of Safar 1400 , $40 \mathrm{f}$.

29 IRPWB 1: 45, Sept. 4, 1981, 22.

${ }^{30}$ Cf. IRPWB 1: 43, Aug. 21, 1981, 24, and IRPWB 1:37, July 10, 1981, 6.

31 Kayhan, Shahrivar 11, 1360/Sept. 2, 1981, 2. 


\section{Indian newspaper praises young martyr}

TEHRAN -- The weekly 1slamic English-language news. paper 'Radiance", published in New Delhi, recently devoted a 21/2 column feature to the memory of a young martyr. Excerpts folluw:

"A fe daysago, the radio and television of the Islamic Republic of Tran had announced that a thirteen year old boy had after fastening several bombs around his wist, jumped before an Iraqi tank. Consequently the enemy tank was blown up with many Iraqi soldiers.

"The mame of that young
martys was Muhammed Husein Fahinidah. Some Guards of the Islamic Revolution paid a visit to the lamily members of the young martyr in Qom. The information obtained through this interview is given in brief.

"Father: Mulnammed Huein was very active boy. He had many virtues. We never naw him do any thing wrong act. He always tried to tread God's path during his studies and also in all other activities. "Mother: My gon's marty. rdom is glorious matter for me. Every one tells me how merciful is Almighty God upon me by ginting an child to me. I am not at all regretful about my son's sacrifice in his path.

"Brother : Even while schooling he had devoted himself to the Islamic Revolution. Once when we heard on radio that thiteen year old boy was killed by throwing himecif beneath a tank, he became angry with parents.

"At that time did not know that he was our own brother. We thought, alas we should have died in his place. Twelve days thereafter the Revolutionary Guards informed us about his martyrdom. They were praising his courage.

"Aunt: We are very pleased that Hussein was martyred in this path. We would not have hesitated to offer cven a greater acripice. Mluse in was a very handsome boy. He loved his mother father and family member very much. He was regular in hig namaz and always obey ang God's order in every respect. He never hurt anybody. He wa alway help ful to all."

"Inna Lillahe Wa Inina Rajeoon".

Fig. 2. (From Tehran Times, Ordibehesht 22nd 1360, May 12th 1981, 2.)

Radjā'i and Bāhonar in IRP's Weekly Bulletin, reproducing the account by the Pars' correspondent (the report was in English):

Pars correspondent in front of the Majlis reported at 8:30 a.m. on 31 st August, 1981 that crowds entered the area while a tape of President Rajai'e was being played for the people. While the people were crying and heading towards Behesht-e Zahra Cementery they shouted: "We are not like the inhabitants of Kufa, to desert Hussein - even if the Ummat dies, the Imam will never be abandoned" ... At 8:45, crowds filled the streets around the Majlis and chanted "Today is the day of mourning, today, Rajaie and Bahonar are with the martyrs." The people also 
shouted: "Death to Banisadr" and "Death to the U.S." and "The Party of Allah may die but it never submits to compromise" ... The crowds of mourners set out at 10:50, while they were beating their chests and crying "Hussein, Hussein", to carry the pure bodies of President Mohammad Ali Rajaie and Prime Minister Mohammad Javad Bahonar to Behesht-e Zahra Cemetery near Tehran. ${ }^{32}$

We know that the cemetery in question served as a centre for the opposition to the Shah. Those killed before and during the Revolution were considered martyrs, and the ritual mourning, especially on the 40th day after death, became political demonstrations, with more victims. Many have observed both the periodicity (every 40th day) of these manifestations and their highly emotional character. ${ }^{33}$ This continued after the Revolution. In connexion with the celebration of the 40th day of the June 28th victims, a speech was held, among others, by the 15 year-old son of Hasan $\bar{A}$ yat-who was murdered a few days earlier. Kayhan reports:

According to the report after the speech of Dr Ayat's son, the crowd of worshippers burst out chanting: "Ayat! Ayat! We swear by your chaste blood that your way is continued'." "The measures of the prosecutor's office perpetuate the revolution, our martyr's blood is awaiting answer." "The armed hypocrite! it is the last moment for you!" "Hezbullah, Hezbullah fights atheism, Hezbullah, Hezbullah will never abandon the scene". ${ }^{34}$ (Hizb Alläh, "God's party").

In all the papers and magazines issued by the present regime in Tehran, the martyr-motif is stressed. Stories constantly appear about those who have sacrificed their lives for the sake of God (i.e. the Islamic Republic). ${ }^{35}$ It is very interesting to note that this concept of religio-political martyrdom also operates in the interpretation of events outside the Muslim world. Official Iran declares its support for the IRA in Northern Ireland and its great sympathy for the "martyrs", the hungerstrikers. A delegation of Iranian Mullās was even sent to Ulster to convey the Islamic Republic's support and sympathy to the IRA. They also visited Bobby Sands' mother, presenting her with a portrait of Imām Khumaynī, all of which was reported and commented upon in the Iranian press. ${ }^{36}$ The Shī ${ }^{-1}$ theologians visiting Ireland recorded with astonishment the lack of enthusiasm among the Catholic priests for the suicidal hunger-strikes.

Even in a hopeless situation where flight or surrender would be possible and more profitable, the martyrdom, the voluntary self-sacrifice, is regard-

${ }^{32}$ IRPWB 1:45, Sept. 4, 1981, 24 and 27. Also in Kayhan, Shahrivar 10, 1360/Sept. 1, 1981, 1.

33 Cf Nyberg, $144 \mathrm{f}, 126$.

34 Kayhan, Mordad 17, 1360/Aug. 8, 1981, 1 and 4.
35 Cf Fig. 2, quoted from Tehran Times, Ordibehesht 22, 1360/May 12, 1981, 2.

36 Cf. e.g. Kayhan, Mordad 21, 1360/Aug. 12, 1981, 3, and Kayhan Shahrivar 1, 1360/Aug. 23, 1981, 6, and Mordad 30/Aug. 23,6 . 
ed as something positive. Several of the "martyrs" during the Revolution and in the war with Iraq fall into the category of death in suicidal actions against the enemy. Such acts are also frequent in the attacks on the IRP regime in Iran. But also those killed unprepared, in ambush or by bombs, are regarded as martyrs.

The highly emotional evaluation of martyrdom sometimes finds expression in remarkable ways. Let me here quote, in its entirety, a eulogy to Ayatullāh Beheshtī after his death in the June 28th outrage. The following prose poem was published in the Sawt al-Umma:

\section{Oh Beheshtī!}

Oh blood of God, shed on the mihrāb of djihād!

Oh blood belonging to God, poured out at the threshold of submission to God and the obedience, which painted the fruits of Islam's tree with its deep-red colour, this colour which will continue to tell our future generations the tale of heroism and of the combat of expiatory sacrifice ( $a l-f i d \vec{a})$, and emit the radiations of power and the charges of resistance in the hearts which beat in faith and determination.

Criminal hands were extended, moved by dark black hearts, and guided by a headquarter of infidels; they were extended from the darkness (or: from the oppressors), in order to pick a generous and pure flower; and so a ripe noble fruit was broken off, and to extinguish a sun among the suns of guidance and truth, and to blunt a sword among the sharp swords of Islam, and to break a javelin among its victorious javelins, and to obliterate a soul among the original and firm souls, and to silence a tongue among the tongues of faith which did not haggle and did not dispute.

The troops of error saw in you the power which threatened their weakness, the originality which vanquished their hypocrisy, and the words of truth and honesty which chase away their vanities and idle talk, and the clarity which tears to pieces the veil of scepticism.

They found in you the tongue of Abu Dharr, the firmness of Maytham, the sublimity of Hagar and the faith of 'Ammār, and they imagined that by killing you they would be able to recover their languishing breath and bring back the /faculty of/ motion to their trembling collapsing body, and the power to their weakened heart.

And it eluded them that the blood of Husayn which appeared from the earth of Karbalä' was the sun which illuminated the paths of the mudjāhids, and that his martyrdom was the resounding cry which awoke the "enveloped ones" and the "covered ones", and frightened God' enemies throughout history ...

And they forgot that the blood of the martyrs on the path of God is the everlasting fuel of the Islamic revolution, and the charges of vigilance and attention, and incitements to power and unity, and reasons for self-sacrifice (fid $\vec{a}$ ) and devotion.

And you fell, Oh Beheshtî!, blood-stained, your blood mingled with the milk of piety, and your body collapsed in order to prostrate before God, having made the /ritual/ ablution with your own blood, the blood of martyrdom, in an eternal prostration $(s u d j \bar{u} d)$. You expired praising God. You expired dressing yourself in the dress of martyrdom, and your pure ghost ascended the ladder of God's pleasure, which it had awaited to meet with desire and patience, just as it had persevered to live in the wounded heart of the Umma, in order to force it to continue on the way 
of truth, which your body followed carefully and your blood served and the water of the pure martyrs ... and /your ghost expired/ as a vow from us to you that we shall persevere, defying the dangers of the long road-we shall not pay any attention to them, and we shall not permit the weariness to trample down our souls, and we invest our blood and our ghosts as a wakf for Islam and the Islamic revolution, until God calls us by his command. "But God makes his light perfect, even if the infidels dislike it". ${ }^{37}$

\section{Comments:}

"Blood of God": The meaning is that Beheshti was so near to God that God is the one who can claim the right to vengeance in accordance with the lex talionis.

Mihräb of djiha ad: A pun. The author alludes to the common root of the words harb, "war", and mihrāb, "niche indicating the direction of prayer". The man of prayer dies as a holy warrior.

Abū Dharr (al-Ghifārī): One of the companions of the Prophet, nowadays often quoted as the representative of "radical socialism" in early Islam, and as a harsh critic of social inequities.

"Ammār (b.Yâsir): In tradition known as a fervent supporter of 'Alī b. Abī Tâlib.

"Enveloped", "covered": Quranic terms (Sura 73 and Sura 74) with special Shī 1 interpretations.

Sudjüd: The metaphor is striking: Beheshtī's body fell down, just as if he were performing the ritual prayer.

Umma: The community of the Muslims.

Wakf: Foundation for religious purposes.

"But God makes etc": Allusion to Sura 61:8 "They want to extinguish with their mouths the light of God, but God makes his light perfect, even if the infidels dislike it".

The wallowing in the sentimentality of blood recurs in the frequent publication of pictures of the blood-stained bodies of the martyrs. ${ }^{38}$ In the editorial of the same issue of Sawt al-Umma the emotional reaction to the June 28th incident makes the writer lose all sense of order and coherence. The article consists of an outpouring of disconnected sentences expressing mourning and faith in the sublimity of martyrdom. This editorial article could itself be called a literary reflection of the Ta ziya ecstasy. ${ }^{39}$

The Ta ${ }^{2}$ ziya, in the sense of the ritual mourning connected with the funeral of those considered martyrs, leads to an excitement, to a frenzy on the part of at least some of the participants, allowing us to speak of ecstasy in the meaning of abnormal states of consciousness. As for the burial of the victims of the June 28th outrage, IRP's Weekly Bulletin says:

\footnotetext{
37 Șawt al-Umma 16, Sha bān 1, 1401/July 15, 1981, 10. The article is signed "Abü Miksdād'".

${ }^{38}$ Cf e.g. the pictures of the corpse and the
}

face of Mutahharī in IRPWB 1:28, May 8 , 1981 , front page, and pages 10 and 16 .

39 Șawt al-Umma 16, Sha bān 1, 1401/July $15,1981,3$. 
... Reports from the cemetery said that because of the massive throng of mourners and their being highly emotional several people became unconscious or were injured. ${ }^{40}$

The pictures published in the newspapers from this occasion, and from the burial of Radjā'i and Băhonar ${ }^{41}$ are also interesting in this respect. And, as we have seen, this taciya excitement expresses, or is channelled into, actual political action.

\section{References}

Periodicals:

Islamic Republic Party Weekly Bulletin. Teheran. (IRPWB).

Kayhan International. Teheran.

Mahjubah. The Magazine for Muslim Women. Teheran.

Sawt al-Umma. Teheran.

ash-Shahid. Teheran.

Tehran Times.

Time. The Weekly Newsmagazine. New York/Amsterdam.

\section{Literature:}

Andrae, T. 1923, 1924, 1925. Der Ursprung des Islams und das Christentum. Kyrkohistorisk Arsskrift.

Berger, P. 1969. The sacred canopy. New York.

Blachère, R. 1949-1951. Le Coran. Traduction selon un essai de reclassement des sourates. Paris.

Ende, W. 1977. Arabische Nation und islamische Geschichte. Beirut.

Hjärpe, J. 1980. Politisk islam. Stockholm.

Hunt, P. 1981. Uppdrag i Iran. Örebro. ${ }^{42}$

Inge, W. R. 1912. Ecstasy. Encyclopaedia of Religion and Ethics.

Kānūn-i asāsī-yi djūmhūrī-yi islāmī-yi Îrān. 1358 (1979). Teheran.

Monchi-Zadeh, D. 1967. Tá ziya, das persische Passionsspiel. Stockholm.

Mutahharī, M. see the following.

Mutahery, M. 1979. The martyr. Karachi. (Also published in Teheran).

Nyberg, E. 1981. Iran i kamp med det förflutna. Stockholm.

Paret, R. 1971. Der Koran. Kommentar und Konkordanz. Stuttgart.

Strothmann, R. 1961. Ta ziya. Shorter Encyclopaedia of Islam.

Sundén, H. 1966. ${ }^{4}$ Religionen och rollerna. Stockholm.

- 1974. Religionspsykologi. Stockholm.

Veccia Vaglieri, 1971. al-Husayn b. 'Alī b. Abī Țālib. Encyclopaedia of Islam.

40 IRPWB 1: 37, July 10, 1981, 9.

41 See Kayhan, Shahrivar 10, 1360/Sept. 1, 1981, 1 and 4, and IRPWB 1: 45 Sept. 4 1981, 24 and 27 , is also interesting in this respect.
42 I have not been able to procure a copy of the original English version of the book (Inside Iran). 